\title{
Relative abundance and habitat use by the frogs Pristimantis shrevei (Stra- bomantidae) and Eleutherodactylus johnstonei (Eleutherodactylidae) on St. Vincent
}

\author{
Carlos Andres Rodríguez Gómez ${ }^{1,2}$, Alondra M. Díaz-Lameiro ${ }^{3,4}$, Craig S. Berg ${ }^{5}$, \\ Robert W. Henderson ${ }^{6}$, and Robert Powell ${ }^{*}$
}

'Department of Biology, University of Puerto Rico, Río Piedras, San Juan, PR 00931

${ }^{2}$ Current address: Proyecto Coquí, San Juan, PR 00931

${ }^{3}$ Department of Biology, University of Puerto Rico at Mayagüez, Mayagüez, PR 00682

${ }^{4}$ Current address: Department of Biological Sciences, Towson University, Towson, MD 21252, USA

${ }^{5}$ Milwaukee County Zoo, Milwaukee, WI 53213, USA

${ }^{6}$ Milwaukee Public Museum, Milwaukee, WI 53233, USA

'Department of Biology, Avila University, Kansas City, MO 64145, USA

*Corresponding Author (robert.powell@avila.edu)

Edited by: S. Blair Hedges. Date of publication: 29 June 2017.

Citation: Rodríguez Gómez CA, Díaz-Lameiro AM, Berg CS, Henderson RW, Powell R. 2017. Relative abundance and habitat use by the frogs Pristimantis shrevei (Strabomantidae) and Eleutherodactylus johnstonei (Eleutherodactylidae) on St. Vincent. Caribbean Herpetology, 58,1-12.

\begin{abstract}
St. Vincent, one of the Windward Islands of the Lesser Antilles, is home to four amphibian species, only one of which (Pristimantis shrevei) is endemic. Pristimantis shrevei (Strabomantidae) is restricted to the highlands, whereas Eleutherodactylus johnstonei (Eleutherodactylidae), an introduced species, has become widely distributed throughout the island. We established and surveyed 26 transects at three sites and recorded the numbers of $P$. shrevei and $E$. johnstonei, encounter rates, and all perch types and heights. In general, $P$. shrevei was more abundant in less disturbed sites at higher elevations and absent from low elevations, whereas $E$. johnstonei was more abundant at lower elevations and in more severely disturbed or altered sites. Both species used elevated perches more frequently than the ground and were not selective regarding microhabitat types.
\end{abstract}

Keywords: competitive displacement, habitat alteration, introduced species, Lesser Antilles, natural history.

Only two species of the genus Pristimantis (Strabomatidae) occur in the West Indies. Pristimantis shrevei (Fig. 1) is a single-island endemic on St. Vincent and P. euphronides is endemic to Grenada. Both species have IUCN Red-List assessments of Endangered (Hedges \& Powell, 2004, 2010), and both have distributions restricted to the highest elevations on their respective islands ( $P$. euphronides $<16 \mathrm{~km}^{2}$ at $300-840 \mathrm{~m}$ above sea level and $P$. shrevei about 90 km² at 275-922 m above sea level; Hedges, 1999; Hedges \& Powell, 2004, 2010; Díaz-Lameiro et al., 2007; Powell \& Henderson, 2007, 2011). In addition, both species are habitat-restricted and appear vulnerable to environmental perturbations, including the presence of the introduced frog, Eleutherodactylus johnstonei (Eleutherodactylidae; e.g., Kaiser, 1997; Fig. 2). The Grenadian P. euphronides has been the subject of extensive fieldwork in recent years (e.g., Harrison et al., 2011; Berg et al., 2013), but the natural history of $P$. shrevei remains largely unknown. Herein we present a quantitative assessment of habitat use by $P$. shrevei and the invasive $E$. johnstonei at several sites on St. Vincent.

St. Vincent is one of the Windward Islands of the Lesser Antilles, the topography (Fig. 3) of which is dominated by the active La Soufrière volcano (elevation 1,220 m). Land uses on the island (CIA, 1995) include arable land (38\%), permanent crops (12\%), meadows and pastures (6\%), forests (41\%), many considerably degraded, and other (3\%). Most remaining natural areas (largely forests) are restricted to the slightly more than $20 \%$ of the 
island designated as protected areas (Chape et al., 2008). St. Vincent is home to four species of amphibians. Two (E. johnstonei and Rhinella marina) are recent human-mediated introductions (e.g., Mallery et al., 2007; Henderson \& Powell, 2009); the third (Leptodactylus validus) also is a recent addition to the fauna that might have been facilitated by human activity (Yanek et al., 2006); only the fourth (P. shrevei) is endemic. Until recently (Heinicke et al., 2007; Hedges et al., 2008), P. shrevei and E. johnstonei were thought to be confamilial and congeneric. Although both species are highly variable in color and pattern (Schwartz \& Henderson, 1991; Díaz-Lameiro et al., 2007), P. shrevei (Fig. 1) is readily distinguished from E. johnstonei (Fig. 2) by distinctive calls and the presence of reddish coloration on the venter and hindlimbs (Díaz-Lameiro et al., 2008).

Pristimantis shrevei is a relatively small frog (male SVL to $28.0 \mathrm{~mm}$, females to $40.1 \mathrm{~mm}$; Kaiser et al., 1994b; Treglia, 2006; Díaz-Lameiro et al., 2007, 2008). The current, presumably limited distribution of $P$. shrevei could be a consequence of human disturbances (e.g., deforestation) and the introduction of E. johnstonei (Powell \& Henderson, 2007, 2011; Sweeney, 2015), which is of comparable size (maximum SVL $35 \mathrm{~mm}$ in females). The latter is widely distributed throughout most of the Lesser Antilles, with introduced populations also known from Jamaica, Guyana, Venezuela, Colombia, and Brazil (e.g., Kaiser \& Hardy, 1994; Kaiser et al., 2002; Henderson \& Powell, 2009; Melo et al., 2014). On St. Vincent, it has become essentially ubiquitous at lower elevations but remains sporadic at the highest elevations.

As the only anuran endemic on St. Vincent, the conservation status of $P$. shrevei is of considerable importance. Although these frogs remain abundant at higher elevations, the relatively restricted distribution and potential vulnerability to chytrid fungal infections are areas of concern (Hedges \& Powell, 2004; Powell \& Henderson, 2007, 2011; Sweeney, 2015, 2016). The presence of the fungus has been documented on other West Indian islands (e.g., Burrowes et al., 2004; Joglar \& Burrowes, 2005; Daltry, 2007, 2011; Díaz et al., 2007; Joglar et al., 2007, 2011; Malhotra et al., 2007, 2011; Henderson \& Powell, 2009) and, most critically, in P. euphronides on Grenada (Harrison et al., 2011; Berg et al., 2013). Means of reducing the likelihood of its arrival on St. Vincent have not been implemented, and Sweeney $(2015,2016)$ confirmed its presence on the island. As on Grenada (Harrison et al., 2011), the temperature and moisture regimes at higher elevations where $P$. shrevei is concentrated provide the most suitable conditions for the fungus. As an introduced species, the conservation status of E. johnstonei on St. Vincent is of interest only in the context of its possible impact on $P$. shrevei.

In this study, we compared encounter rates and habitat use of $P$. shrevei and $E$. johnstonei at various locations on the island in an effort to evaluate the possibility of interspecific competition. The data presented herein, along with those in Sweeney $(2015,2016)$, should facilitate the further development of a conservation plan for $P$. shrevei on St. Vincent.

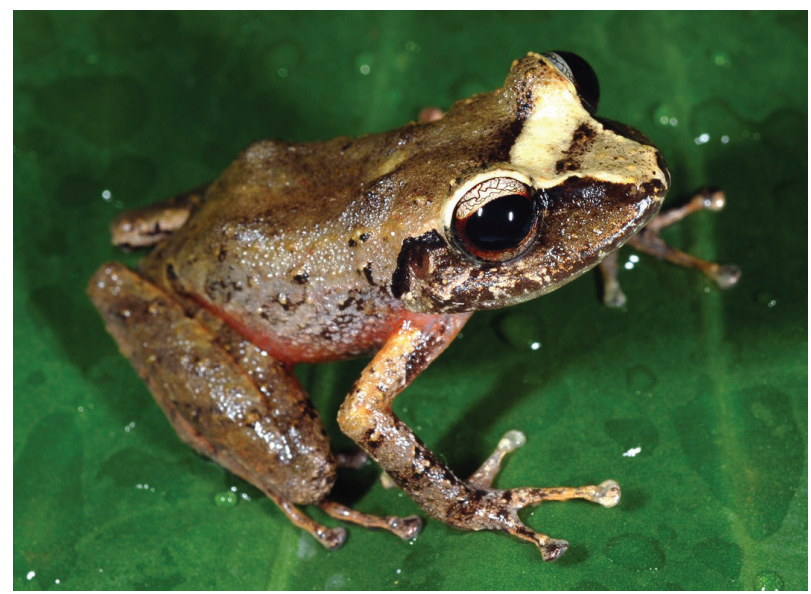

Figure 1. Adult male Pristimantis shrevei from the Vermont Nature Trail, St. Patrick Parish, St. Vincent. Photograph by Robert Powell.

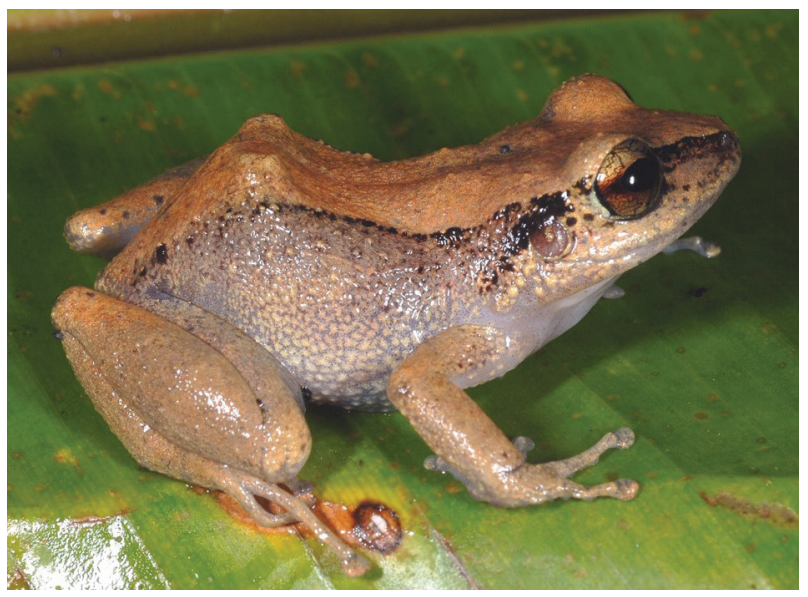

Figure 2. Adult male Eleutherodactylus johnstonei from Bambareaux Beach, St. Patrick Parish, St. Vincent. Photograph by Robert Powell. 


\section{Materials and Methods}

Our study was conducted along the Vermont Nature Trail in the Vermont Nature Reserve (St. Patrick and St. Andrew Parishes), at Bambareaux Beach (north of Layou, St. Patrick Parish), and on La Soufrière (St. David and Charlotte Parishes; Fig. 3). We placed four data loggers (Hobo Pro Series Temp/RH model \# H08-032-08) at Vermont (upland) and Bambareaux (a lowland site) to collect temperature and relative humidty (rh) readings.

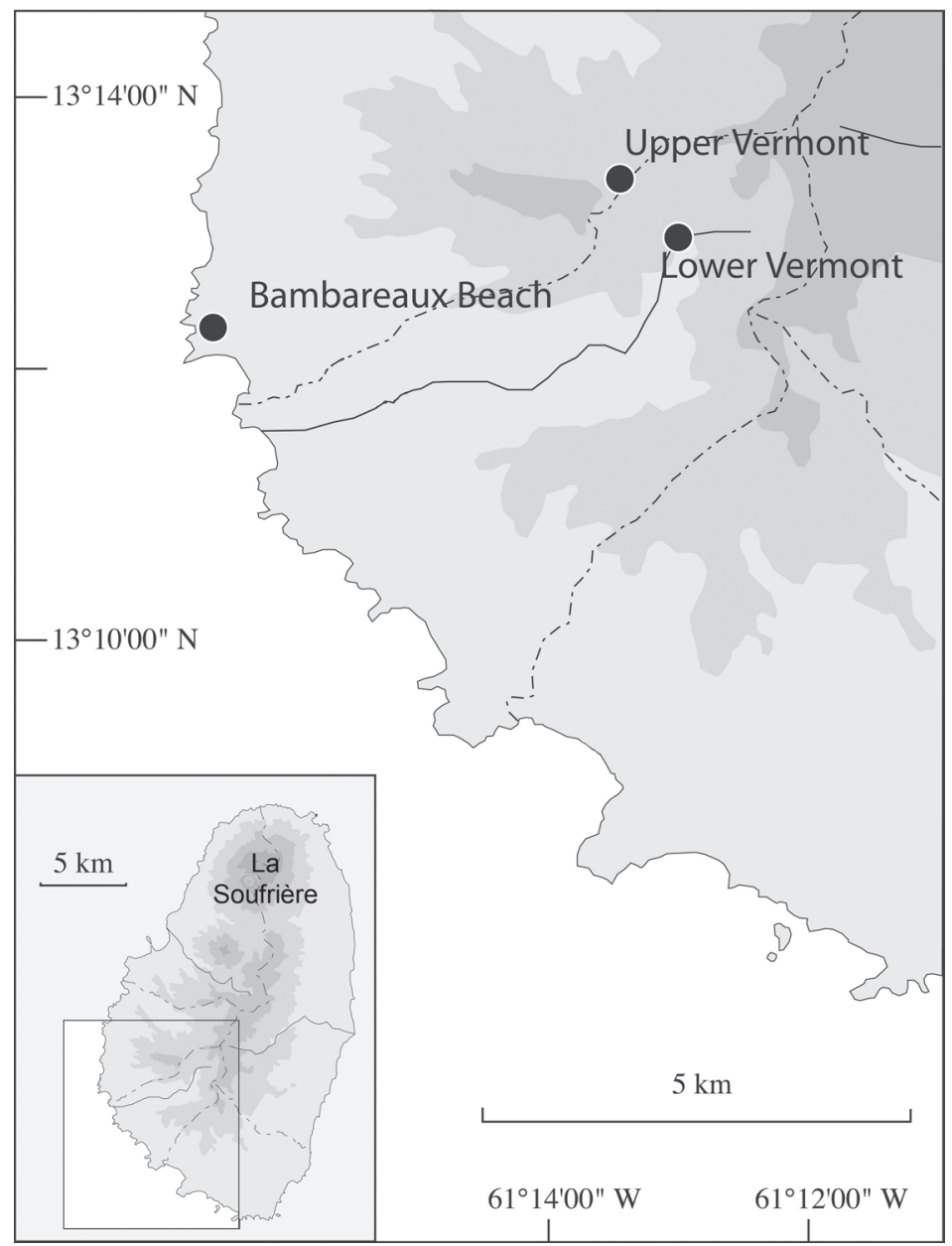

Figure 3. Map of St. Vincent showing locations of study sites. Contour intervals = $300 \mathrm{~m}$.

viduals with SULs $<15 \mathrm{~mm}$ were classified as juveniles.

Because we visited La Soufrière only once, we did not establish and mark transects. Instead, beginning where the path reaches the east side of the crater, we conducted a 30-min timed walk, with four researchers recording the number of $P$. shrevei and $E$. johnstonei along with perch types and heights for each observation. Beginning approximately halfway down the path from the summit, we collected data for an additional $75 \mathrm{~min}$. We used data from La Soufrière only for qualitative purposes, excluding them from statistical analyses due to the different sampling method and lack of habitat characterization.

We characterized microhabitats at sites $1-4$ by visual observation at $5-\mathrm{m}$ intervals along each of the 24 transects (Table 1). Upper Vermont (Site 1; elev. 394-458 m) is rainforest dominated by tall trees (Talipariti elatum, Calophyllum calaba, and Pinus caribaea) with an understory of ferns, heliconias, mosses, lycophytes, grasses, and saplings. The ground was covered extensively with fallen leaves, scattered deadfall, and stumps. Some areas were dissected by rocky streams strewn with boulders. The topography along the trail was variable, with level areas 
alternating with steep to moderate slopes. Soils were moist, average humidity and temperature during the sampling period were $93.6 \%$ and $23.6^{\circ} \mathrm{C}$, respectively. Rainfall in the interior uplands averages approximately 3,750 mm per year (Atlapedia, 1993-2011). The nature trail is located in the St. Vincent Parrot Reserve, a 4,400-ha forested area established as a reserve in 1987 for the protection of one of the few remaining wild populations of the St. Vincent Parrot (Amazona guildingii), and thus providing some protection for other species (e.g., the frogs) in that area (e.g., Powell \& Henderson, 2007, 2011).

Table 1. Microhabitats available for use by Pristimantis shrevei and Eleutherodactylus johnstonei at four sites on St. Vincent. Entries are given as percentages of the total area covered; these were characterized by visual observations at 5-m intervals along each transect. Site 1: Upper Vermont (elev. 394-458 m); Site 2: Lower Vermont (elev. 274-386 m); Sites 3 \& 4: Bambareaux Beach (elev. 3-10 m).

\begin{tabular}{lcccc} 
& \multicolumn{3}{c}{ Site } \\
\hline Microhabitat & $\mathbf{1}$ & $\mathbf{2}$ & $\mathbf{3}$ & $\mathbf{4}$ \\
\hline Bare ground and exposed rocks & 4.9 & 11.1 & 5.8 & 28.2 \\
Epiphytes & 0.5 & 1.6 & 0.0 & 0.0 \\
Attached leaves (including ferns) & 36.9 & 32.2 & 24.9 & 24.7 \\
Small low-lying plants & 17.1 & 14.8 & 5.4 & 7.6 \\
Leaf litter & 31.9 & 34.7 & 45.6 & 30.0 \\
Woody growth & 8.7 & 5.6 & 18.3 & 9.4 \\
\hline
\end{tabular}

Lower Vermont (Site 2; elev. 274-386 m) is secondary forest with a canopy varying from partially open to dense. Trees contributing to canopy formation included Talipariti elatum, Calophyllum calaba, Pinus caribaea, and introduced orchard trees (Theobroma cacao, Artocarpus altilis, and Cecropia sp.). Ground cover varied according to the most abundant types of trees, ranging from thick mats of pine needles or relatively shallow but uniformly scattered leaves from broadleaf species to sparsely scattered leaves, exposed soil, rocks, and deadfall. Also mesic, this habitat has moist soils, but average humidity $(87.8 \%)$ and temperature $\left(24.2^{\circ} \mathrm{C}\right)$ during the sampling period were slightly drier and warmer than along the upper portions of the trail.

Bambareaux Beach (Sites 3 \& 4; elev. 3-10 m) is characterized by lowland dry forest mixed with orchard trees (Mangifera sp., Psidium guajava, and Cocos sp.). The canopy over four transects at Site 3 ranged from complete to fairly open. The understory was dense, with grasses, shrubs, epiphytic and ground orchids, vines, and aerial roots. Ground cover was composed mainly of mango leaves and small fallen branches. Four transects at Site 4 were in a streambed. The canopy was similar to that along transects at Site 3, although the area was rockier with large boulders and bounded by steep inclines with a less dense understory and less abundant ground cover. Located in the rainshadow along the central leeward coast, these sites receive no more and probably less than the 1,500 mm of annual rainfall that characterizes most leeward coastal regions of St. Vincent (Atlapedia, 1993-2011). However, reduced precipitation is somewhat offset by local effects attributable to moisture running off the highlands and collecting in the valley. Average humidity and temperature during the sampling period was $74.4 \%$ and $26.6^{\circ} \mathrm{C}$, respectively.

The summit (elev. 1,220 m) of La Soufrière (Sites $5 \& 6$ ) is the highest point on the island. The most recent eruption was in 1979 (Shepherd \& Sigurdsson, 1982). Consequently, most of the forest on the volcano is secondary growth. Site 5 was close to the crater rim, lacked any semblance of a canopy, was exposed to fog, high winds, and high humidity. The vegetation consisted of low-lying shrubs, "wild pines" (ground bromeliads), mosses, and lycophytes. Slopes were moderate, with only a few level areas, dissected by eroded ravines through volcanic ash, and with many rocks of varying sizes on the surface. Site 6 was approximately halfway down the volcano, with a closed canopy of tree ferns, palms, and a variety of native broadleaf trees. Ground ferns, palm saplings, grasses, epiphytes, vines, heliconias, mosses, liverworts, and lycophytes were common components of the dense understory. The ground was covered with leaves and scattered fallen branches. The area featured sheer drop-offs and steep inclines with numerous exposed rocks.

We used StatView 5.0 (SAS Institute Inc., Cary, North Carolina, USA) for statistical tests; Spearman correlations to compare the number of frogs in each size class encountered in each habitat type, ANOVA to 
compare perch heights of all sex and age classes, Mann-Whitney tests to compare perch heights of adults with those of subadults and juveniles, and two-way contingency tests to compare perch heights. Frogs that could not be assigned to sex or age class or to species (sites $5 \& 6$ only) were not included in statistical analyses but are indicated in figures that illustrate mean perch heights. All means are presented \pm one SE. For all tests, $\alpha \leq 0.05$.

\section{Results}

We encountered far fewer $P$. shrevei $(n=145)$ than $E$. johnstonei $(n=471)$. The former was present at only four of six sites (absent from both Bambareaux Beach sites), whereas the latter was present at all six sites, albeit in very small numbers at the upper Vermont site and on La Soufrière. Encounter rates (Table 2 ) ranged from $0 / \mathrm{h}$ ( $P$. shrevei at Bambareaux Beach and E. johnstonei at the higher elevation on La Soufrière) to $70 / \mathrm{h}$ for $P$. shrevei at the higher elevation on La Soufrière. The latter rate was likely inflated due to a greater number of persons searching for frogs on the volcano. Along the Vermont Nature Trail, the number of E. johnstonei was negatively correlated with elevation $(P<0.001)$, but no significant correlation between numbers and elevation was evident for $P$. shrevei $(P=0.15)$.

Table 2. Encounter rates (frogs encountered per hour) at six surveyed sites on St. Vincent. Site 1: Upper Vermont (elev. $394-458$ m); Site 2: Lower Vermont (elev. 274-386 m); Sites 3 \& 4: Bambareaux Beach (elev. 3-10 m). Note that methods differed at sites 5 \& 6 (see text), where more persons were engaged in searching for frogs and rates are consequently inflated. The asterisk $\left(^{*}\right)$ indicates that no frogs were found along the trail during the timed walk, but a few calling males were heard before the walk and away from the trail.

\begin{tabular}{lcccccc}
\multicolumn{9}{c}{ Site } \\
\hline Species & $\mathbf{1}$ & $\mathbf{2}$ & $\mathbf{3}$ & $\mathbf{4}$ & $\mathbf{5}$ & $\mathbf{6}$ \\
\hline Pristimantis shrevei & 11.50 & 6.50 & 0 & 0 & 70.00 & 33.60 \\
Eleutherodactylus johnstonei & 2.25 & 47.00 & 43.00 & 47.50 & $0^{*}$ & 1.60 \\
\hline
\end{tabular}

On La Soufrière, we encountered 35 P. shrevei during the initial 30-min period at higher elevations. We encountered no $E$. johnstonei during that period, although we did find one male calling from exposed soil just prior to the onset of the timed walk and heard a few other males calling along the path and from nearby small gullies. During the 75-min period at lower elevations on the volcano, we observed 42 P. shrevei but only two E. johnstonei.

Numbers of individuals in various sex and age classes that we encountered in different microhabitats are presented in Tables 3-8. No significant correlation between habitat availability and use was evident for $P$. shrevei at Sites $1 \& 2$ (all $P \geq 0.11$ ), nor were habitat availability and use significantly correlated for E. johnstonei at Sites 1 , $2, \& 3(P=0.09,0.14,0.20$, respectively). However, habitat availability and use for E. johnstonei were significantly correlated at Site $4(P=0.04)$, where bare ground was used far less frequently than its availability.

Table 3. Numbers of frogs encountered along the upper Vermont Nature Trail (Site 1). Microhabitat types: $1=$ bare ground and exposed rocks; 2 = epiphytes; 3 = attached leaves; 4 = leaf litter; 5 = small, low-lying plants (including ferns); 6 = woody growth.

\begin{tabular}{|c|c|c|c|c|c|c|c|}
\hline \multirow[b]{2}{*}{ Species } & \multicolumn{7}{|c|}{ Microhabitat } \\
\hline & 1 & 2 & 3 & 4 & 5 & 6 & Total \\
\hline \multicolumn{8}{|l|}{ Pristimantis shrevei } \\
\hline Adult males & 0 & 3 & 8 & 5 & 1 & 0 & 17 \\
\hline Adult females & 0 & 0 & 1 & 2 & 0 & 0 & 3 \\
\hline Unsexed adults & 0 & 0 & 13 & 1 & 0 & 0 & 14 \\
\hline Subadults & 0 & 0 & 6 & 0 & 0 & 0 & 6 \\
\hline Juveniles & 0 & 0 & 6 & 0 & 0 & 0 & 6 \\
\hline All & 0 & 3 & 34 & 8 & 1 & 0 & 46 \\
\hline \multicolumn{8}{|c|}{ Eleutherodactylus johnstonei } \\
\hline Adult males & 0 & 1 & 3 & 2 & 1 & 1 & 8 \\
\hline Adult females & 0 & 0 & 0 & 0 & 0 & 0 & 0 \\
\hline Unsexed adults & 0 & 0 & 1 & 0 & 0 & 0 & 1 \\
\hline Subadults & 0 & 0 & 0 & 0 & 0 & 0 & 0 \\
\hline Juveniles & 0 & 0 & 0 & 0 & 0 & 0 & 0 \\
\hline All & 0 & 1 & 4 & 2 & 1 & 1 & 9 \\
\hline
\end{tabular}


Table 4. Numbers of frogs encountered along the lower Vermont Nature Trail (Site 2). Microhabitat types: $1=$ bare ground and exposed rocks; 2 = epiphytes; 3 = attached leaves; 4 = leaf litter; 5 = small, low-lying plants (including ferns); 6 = woody growth.

\begin{tabular}{|c|c|c|c|c|c|c|c|}
\hline \multirow[b]{2}{*}{ Species } & \multicolumn{7}{|c|}{ Microhabitat } \\
\hline & 1 & 2 & 3 & 4 & 5 & 6 & Total \\
\hline \multicolumn{8}{|l|}{ Pristimantis shrevei } \\
\hline Adult males & 0 & 0 & 1 & 0 & 0 & 0 & 1 \\
\hline Adult females & 0 & 0 & 0 & 1 & 1 & 0 & 2 \\
\hline Unsexed adults & 0 & 1 & 8 & 2 & 0 & 0 & 11 \\
\hline Subadults & 0 & 0 & 2 & 1 & 2 & 2 & 7 \\
\hline Juveniles & 0 & 0 & 5 & 0 & 0 & 0 & 5 \\
\hline All & 0 & 1 & 16 & 4 & 3 & 2 & 26 \\
\hline \multicolumn{8}{|c|}{ Eleutherodactylus johnstonei } \\
\hline Adult males & 4 & 4 & 26 & 28 & 0 & 19 & 81 \\
\hline Adult females & 0 & 0 & 4 & 2 & 0 & 1 & 7 \\
\hline Unsexed adults & 2 & 3 & 20 & 14 & 3 & 12 & 54 \\
\hline Subadults & 0 & 0 & 3 & 1 & 0 & 3 & 7 \\
\hline Juveniles & 0 & 0 & 23 & 1 & 14 & 1 & 39 \\
\hline All & 6 & 7 & 76 & 46 & 17 & 36 & 188 \\
\hline
\end{tabular}

For both species at all sites, the number of frogs on elevated perches was significantly greater than the number on perches within $30 \mathrm{~cm}$ of the ground (E. johnstonei, $\mathrm{df}=8, \chi^{2}=108.15, \mathrm{P}<0.0001$; P. shrevei, $\mathrm{df}=8, \chi^{2}$ $=16.52, \mathrm{P}=0.04$ ). Perch heights of $P$. shrevei (Fig. 4 ) did not vary significantly among sex and age classes at Sites $1 \&$ $2(\mathrm{df}=4, \mathrm{~F}=1.65, \mathrm{P}=0.18$ and $\mathrm{df}=4, \mathrm{~F}=0.74, \mathrm{P}=0.56$, respectively), nor did those of $E$. johnstonei (Fig. 5 ) at Sites $3 \& 4(\mathrm{df}=2, \mathrm{~F}=0.79, \mathrm{P}=0.46$ and $\mathrm{df}=4, \mathrm{~F}=0.79, \mathrm{P}=0.53$, respectively). However, perch heights of $E$. johnstonei at Site 2 ( $d f=4, F=3.81, P=0.005)$ did differ significantly by sex and age class, with juveniles perched significantly lower than males, females, and unassigned individuals. Perch heights of E. johnstonei at Sites 2, 3, \& 4, where they were most abundant, did not differ significantly by sex and age class ( $\mathrm{df}=4, \mathrm{~F}=2.26, \mathrm{P}=0.06$ ) but adult males (Fisher's PLSD, $P=0.004$ ) and unassigned individuals (Fisher's PLSD, $P=0.01$ ) perched significantly higher than juveniles. Perch heights of all individuals at those three sites did not differ significantly ( $d f=2, F=2.12, P=0.12$ ), but those at Site 3 perched significantly lower than those at Site 2 (Fisher's PLSD, $\mathrm{P}=0.04$ ). The numbers of $E$. johnstonei at Site 1 were too low and the numbers of frogs unassigned to sex and age classes at Sites $5 \& 6$ precluded analyses for those sites. When all frogs at all sites were compared (Fig. 6A), perch heights differed significantly by species, with $P$. shrevei perched significantly higher than $E$. johnstonei $(\mathrm{df}=2, \mathrm{~F}=4.31, \mathrm{P}=0.01)$; when examining only those sites where both species were present (Fig. $6 B$ ), the differences also were significant ( $d f=2, F=5.51, P=0.02$ ).
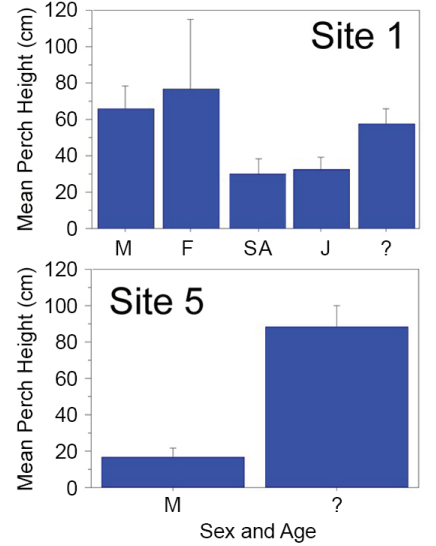

Figure 4. Mean perch heights $(\mathrm{cm})$ of Pristimantis shrevei by sex and age classes. $\mathrm{M}=$ adult males, $\mathrm{F}=$ adult females, $\mathrm{SA}=$ subadults, $\mathrm{J}=$ juveniles, ? = sex undetermined. Error bars $=$ one Standard Error (SE).
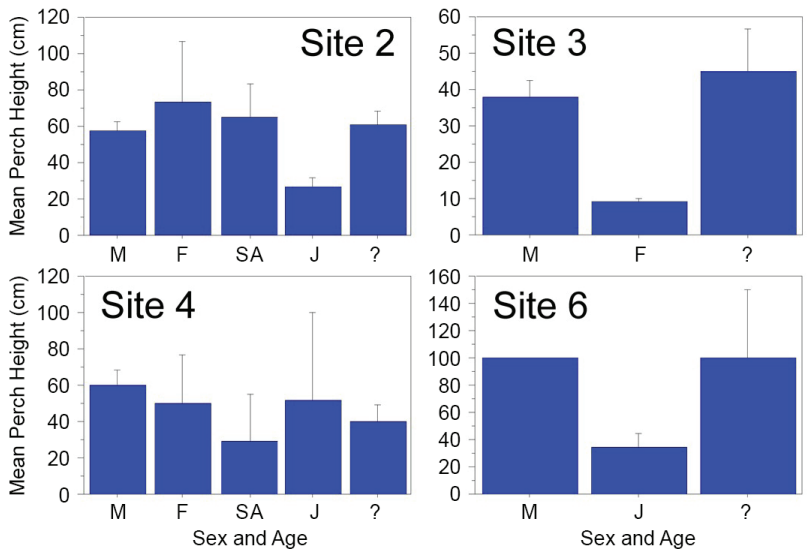

Figure 5. Mean perch heights $(\mathrm{cm})$ of Eleutherodactylus johnstonei by sex and age classes. $\mathrm{M}=$ adult males, $\mathrm{F}=$ adult females, $\mathrm{SA}=$ subadults, $\mathrm{J}=$ juveniles, $?=$ sex undetermined. Error bars $=$ one Standard Error (SE). 
A

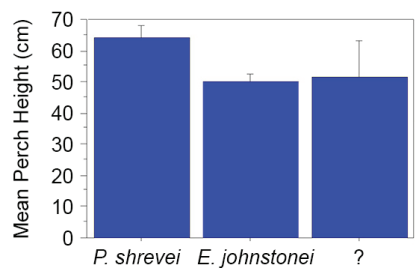

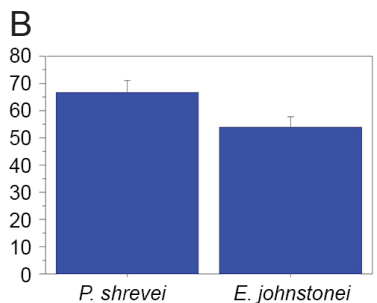

P. shrevei E. johnstonei

Figure 6. Mean perch heights $(\mathrm{cm})$ of Pristimantis shrevei and Eleutherodactylus johnstonei $(\mathbf{A})$ at all sites and $(\mathbf{B})$ at sites where both species were present. Error bars = one Standard Error (SE). A question mark indicates individuals not identified to species.

$$
\text { verance, Montreal, and Fenton, observed similar patterns. Thi }
$$

verance, Montreal and Fenton, observed similar patterns. That P. shreveiwas more abundant in month Rivers, Perseat higher elevations than in mixed forest/orchard situations at slightly lower elevations at Lower Vermont probably reflects the state of the habitat rather than climatic conditions associated with higher elevations.

Table 5. Numbers of frogs encountered at Bambareaux Beach (Site 3). Microhabitat types: 1 = bare ground and exposed rocks; $2=$ epiphytes; 3 = attached leaves; 4 = leaf litter; 5 = small, low-lying plants (including ferns); 6 = woody growth.

\begin{tabular}{|c|c|c|c|c|c|c|c|}
\hline \multirow[b]{2}{*}{ Species } & \multicolumn{7}{|c|}{ Microhabitat } \\
\hline & 1 & 2 & 3 & 4 & 5 & 6 & Total \\
\hline \multicolumn{8}{|c|}{ Eleutherodactylus johnstonei } \\
\hline Adult males & 2 & 0 & 9 & 22 & 6 & 19 & 58 \\
\hline Adult females & 0 & 0 & 0 & 1 & 0 & 2 & 3 \\
\hline Unsexed adults & 4 & 0 & 6 & 4 & 2 & 9 & 25 \\
\hline Subadults & 0 & 0 & 0 & 0 & 0 & 0 & 0 \\
\hline Juveniles & 0 & 0 & 0 & 0 & 0 & 0 & 0 \\
\hline All & 6 & 0 & 15 & 27 & 8 & 30 & 86 \\
\hline
\end{tabular}

Table 6. Numbers of frogs encountered in the streambed at Bambareaux Beach (Site 4). Microhabitat types: $1=$ bare ground and exposed rocks; 2 = epiphytes; 3 = attached leaves; 4 = leaf litter; 5 = small, low-lying plants (including ferns); 6 = woody growth.

\begin{tabular}{|c|c|c|c|c|c|c|c|}
\hline \multirow[b]{2}{*}{ Species } & \multicolumn{7}{|c|}{ Microhabitat } \\
\hline & 1 & 2 & 3 & 4 & 5 & 6 & Total \\
\hline \multicolumn{8}{|c|}{ Eleutherodactylus johnstonei } \\
\hline Adult males & 5 & 1 & 14 & 23 & 3 & 7 & 53 \\
\hline Adult females & 0 & 0 & 1 & 1 & 0 & 1 & 3 \\
\hline Unsexed adults & 4 & 1 & 7 & 14 & 3 & 4 & 33 \\
\hline Subadults & 1 & 0 & 1 & 0 & 1 & 0 & 3 \\
\hline Juveniles & 1 & 0 & 1 & 1 & 0 & 0 & 3 \\
\hline All & 11 & 2 & 24 & 39 & 7 & 12 & 95 \\
\hline
\end{tabular}

Eleutherodactylus johnstonei occurs in clearings or gaps in mesic forests and rainforests but also is tolerant of altered or disturbed habitats (e.g., Schwartz \& Henderson, 1991; Kaiser, 1997; Melo et al., 2014). On St. Vincent, $E$. johnstonei is distributed across the island and is particularly abundant at many lowland locations, including many that have been dramatically altered as a consequence of human activity. It also occurs sporadically in the highlands, where it is sympatric with P. shrevei (Kaiser et al., 1994a; Sweeney, 2015). Although we encountered only a few E. johnstonei at the higher elevations on La Soufrière, Schwartz (1967) included no specimens of E. johnstonei from La Soufrière for his review of the species in the Lesser Antilles and Kaiser et al. (1994a) noted that the species was largely absent from these habitats until after the volcanic eruption in 1979. Apparently, as the habitat recovered from the effects of the eruption, E. johnstonei took advantage of disturbed conditions to occupy areas where previously only $P$. shrevei had occurred.

Both species generally exploited the microhabitats that were available, demonstrating no obvious preference for any particular microhabitat. Only along the low-elevation streambed (site 4) did we see a significant correlation between the number of $E$. johnstonei and habitat type, with a greater number of frogs on exposed 
rocks and the ground, which was the predominant habitat type. Similarly, that frogs perched significantly lower at Site 3 (all E. johnstonei) than Site 2 (both species) probably reflected exploitation of the dense understory at Site 3. That E. johnstonei readily exploited such habitats would appear to reflect the species' generalist tendencies and capacity to exploit disturbed habitats (Kaiser, 1997; Henderson \& Powell, 2001; Mallery et al., 2007; Harrison et al., 2011; Melo et al., 2014).

Table 7. Numbers of frogs encountered at higher elevations on La Soufrière (Site 5). Microhabitat types: $1=$ bare ground and exposed rocks; 2 = epiphytes; 3 = attached leaves; 4 = leaf litter; 5 = small, low-lying plants (including ferns); 6 = woody growth. We encountered no Eleutherodactylus johnstonei during the 30-min survey, although we did find one male calling from exposed soil just prior to the onset of the timed walk and heard a few other males calling along the path and from nearby small gullies.

\begin{tabular}{|c|c|c|c|c|c|c|c|}
\hline \multirow[b]{2}{*}{ Species } & \multicolumn{7}{|c|}{ Microhabitat } \\
\hline & 1 & 2 & 3 & 4 & 5 & 6 & Total \\
\hline \multicolumn{8}{|l|}{ Pristimantis shrevei } \\
\hline Adult males & 2 & 0 & 4 & 0 & 0 & 0 & 6 \\
\hline Adult females & 0 & 0 & 0 & 0 & 0 & 0 & 0 \\
\hline Unsexed adults & 0 & 0 & 17 & 0 & 2 & 0 & 19 \\
\hline Subadults & 0 & 0 & 4 & 0 & 2 & 0 & 6 \\
\hline Juveniles & 0 & 0 & 1 & 0 & 3 & 0 & 4 \\
\hline All & 2 & 0 & 26 & 0 & 7 & 0 & 35 \\
\hline
\end{tabular}

Table 8. Numbers of frogs encountered at lower elevations on La Soufrière (Site 6). Microhabitat types: $1=$ bare ground and exposed rocks; 2 = epiphytes; 3 = attached leaves; 4 = leaf litter; 5 = small, low-lying plants (including ferns); 6 = woody growth.

\begin{tabular}{|c|c|c|c|c|c|c|c|}
\hline \multirow[b]{2}{*}{ Species } & \multicolumn{7}{|c|}{ Microhabitat } \\
\hline & 1 & 2 & 3 & 4 & 5 & 6 & Total \\
\hline \multicolumn{8}{|l|}{ Pristimantis shrevei } \\
\hline Adult males & 0 & 0 & 5 & 0 & 0 & 1 & 6 \\
\hline Adult females & 0 & 0 & 1 & 0 & 0 & 0 & 1 \\
\hline Unsexed adults & 0 & 0 & 25 & 0 & 1 & 4 & 30 \\
\hline Subadults & 0 & 0 & 0 & 0 & 0 & 0 & 0 \\
\hline Juveniles & 0 & 0 & 3 & 0 & 2 & 0 & 5 \\
\hline All & 0 & 0 & 34 & 0 & 3 & 5 & 42 \\
\hline \multicolumn{8}{|c|}{ Eleutherodactylus johnstonei } \\
\hline Adult males & 0 & 1 & 0 & 0 & 0 & 0 & 1 \\
\hline Adult females & 0 & 0 & 0 & 0 & 0 & 0 & 0 \\
\hline Unsexed adults & 0 & 0 & 1 & 0 & 0 & 0 & 1 \\
\hline Subadults & 0 & 0 & 0 & 0 & 0 & 0 & 0 \\
\hline Juveniles & 0 & 0 & 0 & 0 & 0 & 0 & 0 \\
\hline All & 0 & 1 & 1 & 0 & 0 & 0 & 2 \\
\hline
\end{tabular}

We observed most frogs of both species on elevated perches. This might be a consequence of our search mode, during which frogs on higher perches are likely to be more visible. Alternatively, arboreal anuran males might prefer elevated perches for calling to reduce call degradation (e.g., Kime et al., 2000) and possibly extend the range at which the call can be perceived; because calling frogs frequently attracted our attention, most of the frogs we encountered were adult males. The next most frequently encountered class was unsexed adults, a large proportion of which were likely males that were not calling when observed. Because adult females, subadults, and juveniles do not make advertisement calls, they usually are found as a result of chance encounters or a refined search image. However, female E. johnstonei can be found in the vicinity of calling males (Ovaska, 1991) and, in fact, most males and females were on elevated perches, although the number of frogs clearly identified as adult females was too small to confidently support this generalization.

Both species of frogs appeared to utilize perches opportunistically, with perch height and type largely determined by abundance rather than plant type or microhabitat. We found the most frogs on leaves of broadleaved plants or on leaf litter, which at most sites were the most frequently encountered microhabitats. Leaves and trunks provide the elevated perches apparently preferred by adult males (and possibly nearby adult females). 
Eleutherodactylus johnstonei is known to utilize leaf litter for retreat sites and for nesting (Henderson \& Schwartz, 1991; Ovaska, 1991; Bourne, 1997), which is reflected in the number of frogs seen on and in leaf litter. At the higher elevations of La Soufrière, we found most frogs (P. shrevei) on ferns, which were at that site the most abundant elevated perches. Some individuals of both species at all sites perched on exposed rocks and bare soil. In some areas, such as the streambed, rocks are the most readily available elevated perches.

In summary, P. shrevei was more abundant at higher elevations and in relatively undisturbed habitats. On the other hand, E. johnstonei was most abundant at lower elevations and in disturbed or altered sites. Whether biotic and/or abiotic factors limit the numbers of E. johnstonei at higher elevations, or if the species has not yet had enough time to invade the upper elevations on St. Vincent remains to be seen. Certainly, E. johnstonei has entered forested situations on Grenada, where it had not been encountered a decade earlier (e.g., Kaiser \& Henderson, 1994; Germano et al., 2003; Henderson \& Berg, 2006, 2011; Harrison et al., 2011), and Henderson \& Berg (2011) provided statistical evidence that it actually is displacing P. euphronides. On St. Vincent, Sweeney (2015:11) expressed an increased concern about the "ability of $E$. johnstonei to displace $P$. shrevei over a period of time as a result of direct competition in sites where both species are present."

On St. Vincent, both P. shrevei and E. johnstonei appear to prefer elevated perches but indiscriminately use the most readily available perches, suggesting that competition, at least for perches, could be severe in areas of sympatry. Although $P$. shrevei used higher perches at sites where both species were present, suggesting that perch heights might allow niche partitioning, the situation between P. euphronides and E. johnstonei on Grenada suggests that this is likely to be insufficient to preclude competitive exclusion. Similarly, limited ovipositioning sites (e.g., Lips \& Donnelly, 2005) or retreats (e.g., Stewart \& Pough, 1983) could be limiting factors and contribute to competition between these two species. Also, as for P. euphronides on Grenada (Harrison et al., 2011), E. johnstonei exhibits several traits that would likely provide it with a competitive advantage over $P$. shrevei, especially in disturbed habitats. Eleutherodactylus johnstonei is quite tolerant of high temperatures and resistant to desiccation (e.g., Pough et al., 1977). If, also like P. euphronides (Harrison et al., 2011), female P. shrevei attend the eggs and do not feed during this period, this would delay the acquisition of energy reserves for producing another clutch; in $E$. johnstonei, both sexes (but frequently males) attend clutches (e.g., Townsend, 1996). Since chytrid is now known to occur on St. Vincent (Sweeney, 2015, 2016), threats to the continued survival of $P$. shrevei increase substantially. Monitoring the situation is critical in order to determine the ecological relationships between the introduced and endemic species and the potential impact of the chytrid fungus.

\section{Acknowledgements}

John S. Parmerlee, Jr. and Hinrich Kaiser made helpful comments on earlier drafts of this manuscript and the former produced the map. FitzRoy Springer and GlenRoy Gaymes, Department of Forestry, helped in the field. A permit to conduct research on St. Vincent was issued by the Department of Forestry, St. Vincent and the Grenadines. Brian Johnson, Director, Cornelius Richards, Amos Glasgow, and especially FitzGerald Providence facilitated our efforts. Roger Sweeney, Assistant Director of the Virginia Zoo in Norfolk, provided us with a copy of the 2015 Project Report: Conservation Assessment for the St. Vincent Frog. The Zoological Society of Milwaukee provided support for CSB. Fieldwork was funded by a grant from the National Science Foundation (U.S.A.) to Robert Powell (DBI-0242589).

\section{References}

Atlapedia Online (1993-2011) Latimer Clarke Corporation Pty Ltd. (http://www.atlapedia.com/online/countries/ stvince.htm). Accessed April 2017.

Berg CS, Harrison BC, Henderson RW (2013) Pristimantis euphronides, observations in the field and captivity: Conservation implications, pages 109-115. In: Vernier JL, Burac M (Eds.) Biodiversité insulaire: la flore, la faune et 
I'homme dans les Petites Antilles. Actes du Colloque international, Schoelcher, 8-10 Novembre 2010. Direction de l'Environment, de l'Aménagement et du Logement de Martinique and Université de Antilles et de la Guyana, Schoelcher, Martinique.

Burrowes PA, Joglar RL, Green DE (2004) Potential causes for amphibian declines in Puerto Rico. Herpetologica, 60, 141-154.

Chape S, Spaulding M, Jenkins MD (Eds.) (2008) The World's Protected Areas. Status, Values and Prospects in the 21st Century. UNEP World Conservation Monitoring Centre. University of California Press, Berkeley. xv + 365 pp.

CIA (Central Intelligence Agency) (1995) The World Factbook 1995. (https://www.cia.gov/library/publications/resources/the-world-factbook/geos/vc.html). Accessed April 2017.

Daltry JC (2007) An introduction to the herpetofauna of Antigua, Barbuda and Redonda, with some conservation recommendations. Applied Herpetology, 4, 97-130.

Daltry JC (2011) An introduction to the herpetofauna of Antigua, Barbuda and Redonda, with some conservation recommendations, pages 17-51. In: Hailey A, Wilson BS, Horrocks JA (Eds.) Conservation of Caribbean Island Herpetofaunas. Volume 2: Regional Accounts of the West Indies. Brill, Leiden, The Netherlands.

Díaz LM, Cádiz A, Chong A, Silva A (2007) First report of chytridiomycosis in a dying toad (Anura: Bufonidae) from Cuba: A new conservation challenge for the island. EcoHealth, 4, 172-175.

Díaz-Lameiro AM, Powell R, Berg CS (2007) Colour and pattern polymorphism in Pristimantis shrevei and Eleutherodactylus johnstonei (Leptodactylidae) on St. Vincent, West Indies. Herpetological Bulletin, 101, 18-25.

Díaz-Lameiro AM, Kaiser H, Powell R (2008) Pristimantis shrevei. Catalogue of American Amphibians and Reptiles, 844, 1-4.

Germano JM, Sander JM, Henderson RW, Powell R (2003) Herpetofaunal communities in Grenada: A comparison of altered sites, with an annotated checklist of Grenadian amphibians and reptiles. Caribbean Journal of Science, 39, 68-76.

Harrison B, Berg CS, Henderson RW (2011) The Grenada Frog (Pristimantis euphronides): An endemic species in decline and the combined effects of habitat loss, competition, and chytridiomycosis. IRCF Reptiles \& Amphibians, 18, 66-73.

Hedges SB (1999) Distribution patterns of amphibians in the West Indies, pages 211-254. In: Duellman WE (Ed.), Patterns of Distribution of Amphibians: A Global Perspective. Johns Hopkins University Press, Baltimore, Maryland.

Hedges SB, Powell R (2004) Pristimantis shrevei. The IUCN Red List of Threatened Species 2004, e.T56961A11561177. (http://dx.doi.org/10.2305/IUCN.UK.2004.RLTS.T56961A11561177.en). Accessed April 2017.

Hedges SB, Powell R (2010) Pristimantis euphronides. The IUCN Red List of Threatened Species 2010, e. T56593A11491004. (http://dx.doi.org/10.2305/IUCN.UK.2010-2.RLTS.T56593A11491004.en). Accessed April 2017.

Hedges SB, Duellman WE, Heinicke MP (2008) New World direct-developing frogs (Anura: Terrarana): Molecular phylogeny, classification, biogeography, and conservation. Zootaxa, 1737, 1-182.

Heinicke MP, Duellman WE, Hedges SB (2007) Major Caribbean and Central American frog faunas originated by ancient oceanic dispersal. Proceedings of the National Academy of Sciences, 104, 10092-10097.

Henderson RW, Berg CS (2006) The herpetofauna of Grenada and the Grenada Grenadines: Conservation concerns. Applied Herpetology, 3, 197-213.

Henderson RW, Berg CS (2011) The herpetofauna of Grenada and the Grenada Grenadines: Conservation concerns, pages 239-258. In: Hailey A, Wilson BS, Horrocks JA (Eds.) Conservation of Caribbean Island Herpetofaunas. Volume 2: Regional Accounts of the West Indies. Brill, Leiden, The Netherlands.

Henderson RW, Powell R (2001) Responses by the West Indian herpetofauna to human-influenced resources. Caribbean Journal of Science, 37, 41-54.

Henderson RW, Powell R (2009) Natural History of West Indian Reptiles and Amphibians. University Press of Florida, 
Gainesville, Florida. xxiv + 495 pp.

Joglar RL, Burrowes PA (2005) Greater Antilles region progress report. Froglog, 72, 1-2.

Joglar RL, Álvarez AO, Aide TM, Barber D, Burrowes PA, García MA, León-Cardona A, Longo AV, Pérez-Buitrago N, Puente A, Rios-López N, Tolson PJ (2007) Conserving the Puerto Rican herpetofauna. Applied Herpetology, 4, 327-345.

Joglar RL, Álvarez AO, Aide TM, Barber D, Burrowes PA, García MA, León-Cardona A, Longo AV, Pérez-Buitrago N, Puente A, Rios-López N, Tolson PJ (2011) Conserving the Puerto Rican herpetofauna, pages 339-357. In: Hailey A, Wilson BS, Horrocks JA (Eds.) Conservation of Caribbean Island Herpetofaunas. Volume 2: Regional Accounts of the West Indies. Brill, Leiden, The Netherlands.

Kaiser H (1997) Origins and introductions of the Caribbean frog, Eleutherodactylus johnstonei (Leptodactylidae): Management and conservation concerns. Biodiversity Conservation, 6, 1391-1407.

Kaiser H, Hardy JD Jr. (1994) Eleutherodactylus johnstonei. Catalogue of American Amphibians and Reptiles, 581, 1-5. Kaiser H, Henderson RW (1994) The conservation status of Lesser Antillean frogs. Herpetological Natural History, 2 , 41-56.

Kaiser H, Green DM, Schmid M (1994a) Systematics and biogeography of eastern Caribbean Eleutherodactylus (Anura: Leptodactylidae) with the description of a new species from Dominica. Canadian Journal of Zoology, 72, 2217-2237.

Kaiser H, Hardy JD Jr., Green DM (1994b) Taxonomic status of Caribbean and South American frogs currently ascribed to Eleutherodactylus urichi (Anura: Leptodactylidae). Copeia, 1994, 780-796.

Kaiser H, Barrio-Amorós CL, Trujillo JD, Lynch JD (2002) Expansion of Eleutherodactylus johnstonei in northern South America: Rapid dispersal through human interactions. Herpetological Review, 33, 290-294.

Kime NM, Turner WR, Ryan MJ (2000) The transmission of advertisement calls in Central American frogs. Behavioral Ecology, 11, 71-83.

Lips KR, Donnelly MA (2005) Lessons from the tropics, pages 198-205. In: Lannoo W. (Ed.) Amphibian Declines: The Conservation Status of United States Species. University of California Press, Berkeley, California.

Malhotra A, Thorpe RS, Hypolite E, James A (2007) A report on the status of the herpetofauna of the Commonwealth of Dominica, West Indies. Applied Herpetology, 4, 177-194.

Malhotra A, Thorpe RS, Hypolite E, James A (2011) A report on the status of the herpetofauna of the Commonwealth of Dominica, West Indies, pages 149-166. In: Hailey A, Wilson BS, Horrocks JA (Eds.) Conservation of Caribbean Island Herpetofaunas. Volume 2: Regional Accounts of the West Indies. Brill, Leiden, The Netherlands.

Mallery CS Jr., Marcum MA, Powell R, Parmerlee JS Jr., Henderson RW (2007) Herpetofaunal communities of the leeward slopes and coasts of St. Vincent: A comparison of sites variously altered by human activity. Applied Herpetology, 4, 313-325.

Melo MA, Lyra ML, Brischi AM, Geraldi VC, Haddad CFB (2014) First record of the invasive frog Eleutherodactylus johnstonei (Anura: Eleutherodactylidae) in São Paulo, Brazil. Salamandra, 50, 177-180.

Ovaska KE (1991) Reproductive phenology, population structure, and habitat use of the frog Eleutherodactylus johnstonei in Barbados, West Indies. Journal of Herpetology, 25, 424-430.

Pough FH, Stewart MM, Thomas RG (1977) Physiological basis of habitat partitioning in Jamaican Eleutherodactylus. Oecologia, 27, 285-293.

Powell R, Henderson RW (2007) The St. Vincent (Lesser Antilles) herpetofauna: Conservation concerns. Applied Herpetology, 4, 295-312.

Powell R, Henderson RW (2011) The St. Vincent (Lesser Antilles) herpetofauna: Conservation concerns, pages 359376. In: Hailey A, Wilson BS, Horrocks JA (Eds.) Conservation of Caribbean Island Herpetofaunas. Volume 2: Regional Accounts of the West Indies. Brill, Leiden, The Netherlands.

Schwartz A (1967) Frogs of the genus Eleutherodactylus in the Lesser Antilles. Studies on the Fauna of Curaçao and 
Other Caribbean Islands, 24, 1-62.

Schwartz A, Henderson RW (1991) Amphibians and Reptiles of the West Indies: Descriptions, Distributions, and Natural History. University of Florida Press, Gainesville. xvi +720 pp.

Shepherd JB, Sigurdsson H (1982) Mechanism of the 1979 explosive eruption of Soufriere Volcano, St. Vincent. Journal of Volcanology and Geothermal Research, 13, 119-130.

Stewart MM, Pough FH (1983) Population density of tropical forest frogs: Relationship to retreat sites. Science, 221, 570-572.

Sweeney R (2015) Project report: Conservation assessment for the St. Vincent Frog June 2015. Unpublished report submitted to the Forestry Department, Saint Vincent and the Grenadines. 16 pp.

Sweeney R (2016) First detection of the amphibian chytrid fungus (Batrachochytrium dendrobatidis) in St. Vincent and the Grenadines. Herpetological Review, 47, 212-214.

Townsend DS (1996) Patterns of parental care in frogs of the genus Eleutherodactylus, pages 229-239. In: Powell R \& Henderson RW (Eds.) Contributions to West Indian Herpetology: A Tribute to Albert Schwartz. Contributions to Herpetology, volume 12. Society for the Study of Amphibians and Reptiles, Ithaca, New York.

Treglia ML (2006) An annotated checklist of the amphibians and reptiles of St. Vincent, West Indies. Iguana, 13, 252-263.

Yanek K, Heyer WR, de Sá RO (2006) Genetic resolution of the enigmatic Lesser Antillean distribution of the frog Leptodactylus validus (Anura, Leptodactylidae). South American Journal of Herpetology, 1, $192-206$. 